\title{
Islam's Religious Pluralism in Context
}

\author{
Mohammad Hashim Kamali*
}

The current debate in Malaysia as to whether Islam accepts religious pluralism as opposed to mere religious plurality calls for further reflection. Much would depend, it seems, on how one understands religious pluralism and then the three qur'annic verses that characterise Islam.

These proclaim that "surely the religion before Allah is Islam (submission to His will)" (3:19); that "whoever seeks other than Islam as a religion, it will not be accepted from him" (3:85); and "this day I perfected your religion for you, completed My favour to you, and chose Islam to be your faith" (5:3). These are often cited as evidence that Islam is the only true religion and only those who follow Islam shall be saved. Mainstream Qur'ān commentaries consider Islam in these verses to be the exclusive name for the religion revealed to the Prophet Muhammad.

However, Islam is also the primal religion of submission preached by Adam to all his posterity who accepted God as their Lord, as in the divine invocation: "Am I not your Lord? They said: yes we do testify" (7:172). All humankind then, before time began, professed Islam in its widest sense of submission. Understood in this way, the verses before us recognise the validity of every religion that requires submission to God's will. This understanding of Islam also tallies well with the essence of universality that Islam manifests in its own messages, values and objectives.

Toshiko Izutsu has convincingly demonstrated that in several qur'ānic verses Islam can be taken to present every previous revelation as a way of submitting, and that such verses present Islam as a universal religion. The first to declare himself a Muslim in the Qur'ān is the Prophet Noah: "I was commanded to be among the submitters (muslimin)" (10:72). Concerning Abraham: "His Lord said to Abraham: submit. He said I submit to the Lord of the worlds" (2:31). The succeeding verse recounts that both Abraham and Jacob advised their sons: "Allah has chosen the religion for you. So do not die except in a state of submission (muslimūn)." Every prophet of the Judaeo-Christian tradition has thus taught a different mode of submission to God. If Islam is taken to mean submission in the Qur'ān rather than an institutionalised creed, it would pave the way for "a very eloquent understanding of religious pluralism, one wherein all revelations throughout history are seen as different ways of giving to God that which is most difficult to give - our very selves".

* Mohammad Hashim Kamali is the Chairman and CEO of IAIS Malaysia. An earlier version of this Viewpoint appeared on 8 February 2011 in The New Straits Times (Kuala Lumpur). 
Furthermore, imān (faith) which rests at the heart of Islam occupies a much larger space in the Qur'ān, occurring hundreds of times, whereas Islam occurs on only eight occasions. Imann consists of a state of mind, manifested in the testimonial of the faith (kalimah shahādah), whereas Islam consists mainly of conduct - as in the Five Pillars of the faith. Submission is sometimes said to be the very first step, but perhaps a shallow one if it is not espoused by $\bar{i} m \bar{a} n$ - as indicated in the following verse: "The Bedouin say: We believe (ämannā); Say to them 'you do not believe.' Rather say 'we have surrendered (aslamnā)', for $\bar{i} m \bar{a} n$ has not permeated your hearts [...]" ( 49:14).

\section{Plurality vis-à-vis Pluralism}

Unlike plurality which may lack interaction and engagement, pluralism is interactive in that it entails recognition and acceptance of the different other for what he is, not necessarily embracing all that he may believe or disbelieve.

In the context of theology, religious pluralism is treated under the three headings of exclusivist, inclusivist, and pluralist. The exclusivists believe that only their faith is true and all others are false; the inclusivists hold that their faith is true and others are included in it in some sense. The pluralists maintain that all faiths are true and show different paths to the same Reality. Religious pluralism of this last variety is difficult to maintain under most religions, including Islam. Yet the Qur'ān is clearly expressive of the inclusivist impulse of Islam:

Say, we believe in God and that which has been sent down to us and [...] to Abraham and Ishmael, Isaac and Jacob, [...] to Moses, Jesus, and the Prophets from their Lord; we make no distinction whatsoever between them, surrendering as we do unto Him (lahu muslimūn). (3:84)

Islam recognises all monotheistic religions and entitles the followers of other religions to practise their own beliefs, personal laws and custom. If the essence of religious pluralism is recognition, co-existence and cooperation with people of different religious persuasions within the same society, then Islam is pluralist. Lexicological accuracies apart, some have argued that no civilisation in history has demonstrated a more resolute commitment to pluralism than Islam. Not only the Qur'ān but also the renowned so-called 'Constitution of Medina' are affirmative on religious pluralism. This document proclaimed the "Emigrants (al-muhäjirūn), the Helpers (al-anșār) and the Jews as one community (ummah)", and left open the possibility for others to join them in the spirit of unity and good will. In this writer's view, this is categorical evidence of Islam's inclusivity and openness and is also illustrating the Prophet's judicious pragmatism at the expense almost of semantic 
accuracy. For ummah by definition signifies unity in faith. Yet the Prophet went beyond that in the interest evidently of social harmony and cohesion.

In a paper Yūsuf al-Qaraḍāwī presented on "Pluralism from the Perspective of Islam", ${ }^{1}$ he discussed religious pluralism (al-ta 'addudiyyah al-dinniyyah); using this phrase, in preference to parallel expressions such as ta 'addudiyyat al-adyān, kathrat al-adyān (religious plurality), al-Qaraḍāwī maintained that religious pluralism was a normative Islamic position. He also reviewed the three above-mentioned verses but did not think that they could be used as evidence to say that Islam decried other religions. For "this would be fanaticism [...]. Some Muslim brethren have erred in concluding from these verses that no religion other than Islam is valid." For in numerous other passages the Qur'ān recognises other religions, even that of the idolator, as in the Sürah al-Käfirūn (109:6): "to you is your religion and to me, my religion".

\section{Conclusion and Recommendation}

- The said three verses undoubtedly entitled the Muslims to say that Islam is a true religion, but they stop short of denying others to hold the same about their religions.

- Salvation too in the Qur'ān is granted, not only to Muslims, but to all those who believe in God and do good deeds (2:62; 5:69).

- Muslims (and in particular their governments) should follow the precepts of their sources and the practice of their Prophet in this regard.

\section{Note}

1. At a conference in Amman, Jordan, on 21 August 2004, an event at which this writer was present. 